\title{
Antimicrobial, antioxidant and cytotoxicity potential of Manihot multifida (L.) Crantz (Euphorbiaceae)
}

\author{
RODRIGO L. FABRI ${ }^{1}$, DANIEL S. DE SÁ ${ }^{2}$, ANA PATRÍCIA O. PEREIRA ${ }^{2}$, \\ ELITA SCIO $^{1}$, DANIEL S. PIMENTA ${ }^{2}$ and LUCIANA M. CHEDIER ${ }^{2}$ \\ ${ }^{1}$ Laboratório de Produtos Naturais Bioativos, Departamento de Bioquímica, Instituto de Ciências \\ Biológicas, Universidade Federal de Juiz de Fora, 36036-900 Juiz de Fora, MG, Brasil \\ ${ }^{2}$ Departamento de Botânica, Instituto de Ciências Biológicas, Universidade Federal \\ de Juiz de Fora, Cidade Universitária, 36036-900 Juiz de Fora, MG, Brasil
}

Manuscript received on June 17, 2013; accepted for publication on July 30, 2014

\begin{abstract}
Manihot multifida (L.) Crantz (Euphorbiaceae) is widely used in popular medicine for the treatment of infected wounds. This study evaluated the in vitro antioxidant and antimicrobial potential of this species against strains of Gram-positive and Gram-negative bacteria and fungi, known to cause infections in humans. The extracts showed minimal inhibitory concentration (MIC) varying from 39 to $2500 \mu \mathrm{g} / \mathrm{mL}$ for antimicrobial activity. The methanolic extract of fruits, aqueous and hexane extracts of leaves showed a very strong activity against Candida albicans (ATCC 18804) with MIC of $39 \mu \mathrm{g} / \mathrm{mL}$. Furthermore, the methanolic extract of M. multifida leaves exhibited DPPH (1,1-diphenyl-2-picrylhydrazyl) scavenging potential with inhibitory concentration $\left(\mathrm{IC}_{50}\right)$ values of $46.9 \mu \mathrm{g} / \mathrm{mL}$, followed by hexane extract of leaves with $\mathrm{IC}_{50}$ values of $59.2 \mu \mathrm{g} / \mathrm{mL}$. The cytotoxic activity against brine shrimp was stronger for the methanolic extract of leaves (lethal concentration - $\mathrm{LC}_{50}$ of $15.6 \mu \mathrm{g} / \mathrm{mL}$ ). These results suggest that M. multifida has interesting antimicrobial and antioxidant activities. Moreover, these results corroborate the popular use of this specie in treating fungal infections since it demonstrates significant activity against $C$. albicans.
\end{abstract}

Key words: antimicrobial, antioxidant, Candida albicans, cytotoxicity, Manihot multifida.

\section{INTRODUCTION}

Manihot multifida (L.) Crantz (Euphorbiaceae) (= Jatropha multifida L.) is commonly used in Brazilian folk medicine to treat wounds and gastrointestinal ulcers (Buch et al. 2008). In Asia and Africa it is used for the treatment of infected wounds, skin infections and scabies (Kosasi et al. 1989).

Martins et al. (2005) developed a study with eight plant species, including M. multifida and

Correspondence to: Luciana Moreira Chedier

E-mail: luciana.chedier@ufjf.edu.br found antiseptic and antifungal activity for this species. Another study developed by Aiyelaagbe et al. (2008) in Nigeria, with methanol and hexane extracts of leaves, roots and stems of $M$. multifida also showed the antimicrobial activity of this species, and for some micro-organisms this effect was even greater than the control drug. The methanol and ethyl acetate extracts of stem wood and bark showed higher activity against Proteus mirabilis than gentamicin, and among the extracts, stem and root methanolic 
extracts showed antimicrobial activity against Pseudomonas aeruginosa resistant to gentamicin.

Hamza et al. (2006) verified the accuracy of the biological activities of these species according to ethnopharmacology and concluded that the methanolic extracts of leaves, stems and roots from M. multifida have strong activity against Candida sp. and Cryptococcus neoformans.

In order to validate the popular use of Manihot multifida (L.), this study examined the in vitro antioxidant and antimicrobial potential of this species against strains of Gram-positive and Gram-negative bacteria and fungi, known to be causing infections in humans. A preliminary phytochemical screening fir the identification of the major components of the special metabolism was also conducted and cytotoxicity was determined by brine shrimp lethality bioassay.

\section{MATERIALS AND METHODS}

\section{Plant Material}

The leaves and fruits were collected in Juiz de Fora,

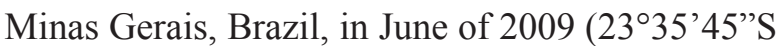
$46^{\circ} 43^{\prime} 45^{\prime}$ 'W). Voucher specimens were deposited in the Herbarium Leopoldo Krieger (CESJ) of the Federal University of Juiz de Fora (number 54865).

\section{PREPARATION OF THE EXTRACT}

The leaves (136.6g) were powdered and separated into two fractions. One of them (66.1g) was macerated with hexane and methanol, successively $(3 \times 200 \mathrm{~mL})$ for five days at room temperature. After evaporation of the solvent under reduced pressure at $45^{\circ} \mathrm{C}$, the respective hexane $(6.5 \mathrm{~g})$ and methanolic $(15.5 \mathrm{~g})$ extracts were obtained. The other fraction $(70.5 \mathrm{~g})$ was submitted to infusion and subsequent lyophilization to obtain the aqueous extract $(23.8 \mathrm{~g})$.

The fruits (47.8g) were powdered and macerated with hexane and methanol, successively $(3 \times 200 \mathrm{~mL})$ for five days at room temperature.
After evaporation of the solvent under reduced pressure at $45^{\circ} \mathrm{C}$, the respective hexane $(6.2 \mathrm{~g})$ and methanolic $(3.4 \mathrm{~g})$ extracts were obtained.

All the extracts were kept in tightly stoppered bottles under refrigeration until used for the biological testing and phytochemical screening.

\section{High-PERFORMANCE LiQUid CHROMATOGRAPHY}

(HPLC) ANALYSIS

These analyses were performed on a Shimadzu LC10 Instrument, two LC-10 AT pumps, a Rheodyne 7725 injector with $20 \mu 1$ loop and a photodiode array detector SPD-M10A. The column employed was a Zorbax SB-18; 250 x 4.6mm, $5 \mu \mathrm{m}$ particle size. A linear gradient of a binary solvent system, A:B, which varied from 0 to $100 \% \mathrm{~B}$ was run at a flow rate of $1 \mathrm{~mL} / \mathrm{min}$ over sixty minutes where A consisted of acetonitrile: $\mathrm{H}_{2} \mathrm{O}, 5: 95$, with $0.05 \%$ TFA and $\mathrm{B}$ consisted of acetonitrile: $\mathrm{H}_{2} \mathrm{O}, 65: 35$, with $0.05 \%$ TFA. The mobile phase was returned to its original composition over the course of $60 \mathrm{~min}$, and an additional 10 min were allowed for the column to re-equilibrate before injection of the next sample. The sample volume was $20 \mu \mathrm{l}$ at a concentration of $1 \mathrm{mg} / \mathrm{mL}$ and the temperature was maintained at $25^{\circ} \mathrm{C}$ during the analysis. Detection was performed simultaneously at 220, 270, 335 and $360 \mathrm{~nm}$.

\section{GAS CHROMATOGRAPHY / MASS SPECTROMETRY (GC/MS)}

This analysis was carried out using a Hewlett Packard 6890 gas chromatograph equipped with a fused silica capillary column $(\mathrm{HP}-5,30 \mathrm{~m} \times 0.25 \mathrm{~mm}$, $0.25 \mu \mathrm{m}$ film thickness), helium as carrier gas with a flow rate $1.0 \mathrm{~mL} / \mathrm{min}$; temperature programming from $70^{\circ} \mathrm{C}$ to $290^{\circ} \mathrm{C}\left(2{ }^{\circ} \mathrm{C} / \mathrm{min}\right)$, coupled to a Hewlett-Packard 5972 mass spectrometer. The MS operating parameters were: $70 \mathrm{eV}$, ion source $250^{\circ} \mathrm{C}$ equipped with EI. The compound identification was carried out by comparison of their retention indices (RI) with literature values; and the MS data with those from Wiley 275.1 mass spectral data base. 


\section{DPPH RADICAL SCAVENGING}

The free radical scavenging activity of sample solutions in methanol was determined based on their ability to react with stable 1,1-diphenyl-2picrylhydrazyl (DPPH) free radical (Govidarajan et al. 2003). The plant samples at various concentrations ( 7.8 to $250 \mu \mathrm{g} / \mathrm{mL}$ ) were added to a $152 \mu \mathrm{M}$ solution of DPPH in methanol. After incubation at $37^{\circ} \mathrm{C}$ for $30 \mathrm{~min}$, the absorbance of each solution was determined at $517 \mathrm{~nm}$. The antioxidant activity of the samples was expressed as $\mathrm{IC}_{50}$ (inhibitory concentration), which was defined as the concentration (in $\mu \mathrm{g} / \mathrm{mL}$ ) of sample required to inhibit the formation of DPPH radicals by $50 \%$. As positive control, rutin was used.

\section{CYTOTOXICITY ASSAY}

Brine shrimp lethality bioassay (Meyer et al. 1982) was carried out to investigate the cytotoxicity of the extracts. Brine shrimp (Artemia salina Leach) eggs were hatched in a beaker filled with seawater under constant aeration. After $48 \mathrm{~h}$ the nauplii were collected by pipette and were counted macroscopically in the stem of the pipette against a lighted background. Solutions of the extracts were made in seawater containing $1 \%$ DMSO, at varying concentrations (10 to $1000 \mu \mathrm{g} / \mathrm{mL}$ ) and incubated in triplicate vials with 10 brine shrimp larvae. After $24 \mathrm{~h}$ of incubation, the nauplii were examined against a lighted background, with a magnifying glass and the number of survivors in each vial was counted and noted. Both positive (thymol) and negative (sea water containing 1\% DMSO) control assays were carried out in order to verify the susceptibility of $A$. salina under assay conditions employed. $\mathrm{LC}_{50}$ was determined from $24 \mathrm{~h}$ counts. The general toxicity activity was considered weak when $\mathrm{LC}_{50}$ was above $250 \mu \mathrm{g} / \mathrm{mL}$.

\section{MicROBIAL STRAINS}

The samples were evaluated against a panel of micro-organisms, including the bacterial strains
Staphylococcus aureus (ATCC 6538), Streptococcus pyogenes (ATCC 10096), Salmonella enterica sorovar typhimurium (ATCC 13311), Escherichia coli (ATCC 10536), Bacillus cereus (ATCC 11778), and the yeast Candida albicans (ATCC 18804). Bacterial strains were cultured overnight at $37^{\circ} \mathrm{C}$ in Mueller Hinton agar (MHA). C. albicans was cultured for $48 \mathrm{~h}$ at $30^{\circ} \mathrm{C}$ in Sabouraud dextrose agar (SDA).

SERIAL Dilution ASSAY FOR DETERMINATION OF THE

MINIMAL INHIBITORY CONCENTRATION (MIC)

The minimal inhibitory concentration (MIC) of each extract was determined by using the broth microdilution techniques as described by the National Committee for Clinical Laboratory Standards (NCCLS/CLSI 2002). MIC values were determined in RPMI 1640 buffered to $\mathrm{pH}$ 7.0 with MOPS for yeast and in Mueller Hinton broth (MHB) for bacteria. C. albicans was cultured at $30^{\circ} \mathrm{C}$ for $48 \mathrm{~h}$ in SDA, and bacteria were cultured at $37^{\circ} \mathrm{C}$ for $24 \mathrm{~h}$ in MHA. Sample stock solutions were diluted from 5000 to $2.5 \mu \mathrm{g} /$ $\mathrm{mL}$ (final volume $=80 \mu \mathrm{l}$ ) with a final DMSO concentration $1 \%$. Then, RPMI or MHB (100 $\mu 1)$ was added to microplates. Lastly, $20 \mu 1$ of $10^{6} \mathrm{CFU} / \mathrm{mL}$ of standardized yeast and bacterial suspensions were placed in microplates and the test was performed in a volume of $200 \mu 1$. Plates were incubated at $30^{\circ} \mathrm{C}$ for $48 \mathrm{~h}$ for yeasts and at $37^{\circ} \mathrm{C}$ for $24 \mathrm{~h}$ for bacteria. The same tests were performed simultaneously for growth control (RPMI + yeast and MHB + bacteria) and sterility control (RPMI or MHB + extract). As positive control, amphotericin $\mathrm{B}$ and chloramphenicol, were used. The MIC values were calculated as the highest dilution showing complete inhibition of the tested strain.

\section{QUANTITATIVE EVALUATION OF ANTIMICROBIAL ACTIVITY}

The antimicrobial activity of plant extracts may be expressed in different ways based on technique used. The micro-dilution method yields MIC 
values, the minimum concentration at which inhibition is observed $(\mu \mathrm{g} / \mathrm{mL})$. In this work, methods other than numerical values were used to express antimicrobial efficiency. Beside results being recorded in terms of MIC $(\mathrm{mg} / \mathrm{mL})$, total activity values were employed, as well as percent activity values. These demonstrate the total antimicrobial potency of particular extracts and the microbial susceptibility index (MSI), which is used to compare the relative susceptibility among the microbial strains (Eloff 2004):

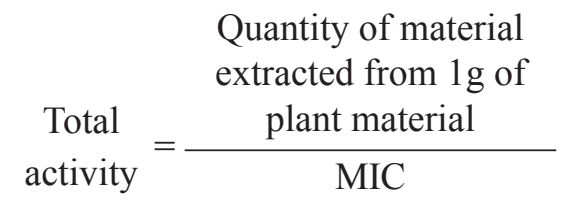

These values would indicate the largest volume to which biologically active compounds in $1 \mathrm{~g}$ of plant material can be diluted and still inhibit microbial growth.

$\begin{array}{cc}\text { Percent } & \begin{array}{c}100 \times \text { number of } \\ \text { activity } \\ \text { a specific extract }\end{array} \\ (\%) & \begin{array}{c}\text { Total number } \\ \text { of tested microial } \\ \text { strains }\end{array}\end{array}$

The percent activity demonstrates the total antimicrobial potency of particular extracts. It shows the number of microbes found susceptible to one particular extract.

$$
\text { MSI }=\frac{\begin{array}{c}
100 \mathrm{x} \text { number of extracts } \\
\text { effectve against each } \\
\text { microbial strain }
\end{array}}{\text { Number of total samples }}
$$

MSI is used to compare the relative susceptibility among the microbial strains. MSI values ranges from ' 0 ' (resistant to all samples) to ' 100 ' (susceptible to all samples).

\section{STATISTICAL ANALYSIS}

The $\mathrm{IC}_{50}$ for antioxidant activity and the $\mathrm{LC}_{50}$ for cytotoxicity activity were calculated using Grafit 5 software and Probit analysis, respectively. Statistical differences between the treatments and the control were evaluated by ANOVA test.

\section{RESULTS AND DISCUSSION}

\section{PHYTOCHEMICAL SCREENING}

Phytochemical screening results of the samples are given in Table I. All samples presented phenols and flavonoids.

TABLE I

Yield (\% w/w) and phytochemical screening of the Manihot multifida extract.

\begin{tabular}{cccccc}
\hline & \multicolumn{3}{c}{ Leaves } & \multicolumn{2}{c}{ Fruit } \\
\cline { 2 - 6 } Phytocompounds & $\begin{array}{c}\text { Hexane } \\
\text { extract } \\
\mathbf{( 9 . 8 )}\end{array}$ & $\begin{array}{c}\text { Methanolic } \\
\text { extract } \\
\mathbf{( 2 3 . 4 )}\end{array}$ & $\begin{array}{c}\text { Aqueous } \\
\text { extract } \\
\mathbf{( 3 3 . 8 )}\end{array}$ & $\begin{array}{c}\text { Hexane } \\
\text { extract } \\
\mathbf{( 1 3 . 0 )}\end{array}$ & $\begin{array}{c}\text { Methanolic } \\
\text { extract } \\
\mathbf{( 7 . 1 )}\end{array}$ \\
\hline Phenols & + & + & + & + & + \\
Flavonoids & + & + & + & + & + \\
Coumarins & - & - & - & - & - \\
Saponins & - & - & - & - & - \\
Taninns & - & - & - & - & - \\
Sterols & + & + & - & - & - \\
Triterpenoids & + & - & - & + & + \\
Anthraquinones & - & - & - & - & - \\
Alkaloids & - & - & - & - & - \\
\hline
\end{tabular}

$+=$ positive reaction; - = negative reaction. 
HPLC analyses at $220 \mathrm{~nm}$ (Fig. 1) showed that the aqueous and methanolic leaves extracts showed phenylpropanoids (UVmax: 286, 525 and 529) and flavones (UVmax: 269, 337 and 524), as main constituents. Fruits methanolic extract presented different phenylpropanoids (UVmax: 285, 288 and 423) and flavones (UVmax: 285, 305, 313) comparing to those found in leaves extracts.

GC/MS analyses for the hexanic leaves extract presented a major signal $(54.53 \%)$ at $47.67 \mathrm{~min}$, which mass spectrum $(\mathrm{m} / \mathrm{z}$ 424) suggested that the compound is a pentacyclic triterpenoid with a lupane basic type. This compound was identified by comparison of the MS data with those from Wiley 275.1 mass spectral data base.

Results found in literature showed the compound biflavone-di-C-glycoside isolated from J. multifida leaves (Moharram et al. 2007) and macrociclic diterpenoids of stems and roots (Aiyelaagbe et al. 2007, Das et al. 2008, 2009).

\section{ANTIOXIDANT ACTIVITY}

The methanolic extract of $M$. multifida leaves exhibited the lowest DPPH scavenging potential with $\mathrm{IC}_{50}$ values of $46.9 \mu \mathrm{g} / \mathrm{mL}$, followed by the hexane extract of leaves with $\mathrm{IC}_{50}$ values of $59.2 \mu \mathrm{g} /$ $\mathrm{mL}$ (Table II), indicating that these fractions have a good potential as free radical scavengers. The control rutin showed $\mathrm{IC}_{50}$ values of $1.4 \mu \mathrm{g} / \mathrm{mL}$. Polyphenols, particularly flavonoids, which were found in all extracts of M. multifida, and are also widely distributed in the plant kingdom and present in considerable amounts in fruits, vegetables, spices, medicinal herbs and beverages, have been used to treat many human diseases, such as diabetes, cancers and coronary heart diseases (Broadhurst et al. 2000).

Moreover, flavonoids have been shown to exhibit antioxidative, antiviral, antimicrobial and antiplalet activities (Middleton and Kandaswami 1992). The biological activities of these polyphenols in different systems are believed to be due their redox properties, which can play an important role in absorbing and neutralizing free radicals, quenching singlet and triplet oxygen, or decomposing peroxides (Osawa 1994).

\section{CYTOTOXICITY}

The methanolic extract of leaves exhibited significant cytotoxicity activity against Artemia salina $\left(\mathrm{LC}_{50} 15.6 \mu \mathrm{g} / \mathrm{mL}\right)$, followed by hexane and methanol extracts of fruits $\left(\mathrm{LC}_{50} 34.1\right.$ and $89.8 \mu \mathrm{g} / \mathrm{mL}$, respectively) (Table II) as $\mathrm{LC}_{50}$ values $<250 \mu \mathrm{g} / \mathrm{mL}$ are considered significant for crude extracts (Rieser et al. 1996). The brine shrimp lethality assay is based on the ability to kill laboratory-cultured Artemia salina nauplii and is considered to be one of the most useful tools for the preliminary assessment of general toxicity (McLauglin et al. 1991).

McLaughlin et al. (1998) correlated the toxicity against $A$. salina with the toxicity against human solid tumor cell lines. Those results suggest that this method can be employed as a preliminary analysis of cytotoxicity of novel substances. The diterpenoid multifidone isolated from $M$. multifida showed significant decrease in cell viability in four different cancer cell lines (Das et al. 2009).

\section{ANTIMICROBIAL ACTIVITY}

The MIC values obtained from this study for all samples tested ranged from 2500 to $39 \mu \mathrm{g} / \mathrm{mL}$. Aligiannis et al. (2001) proposed a classification for plant materials, based on MIC results as follows: strong inhibitors - MIC up to $500 \mu \mathrm{g} / \mathrm{mL}$; moderate inhibitors - MIC between 600 and $1500 \mu \mathrm{g} / \mathrm{mL}$; weak inhibitors - MIC above $1600 \mu \mathrm{g} / \mathrm{mL}$. The methanolic extract of fruits, aqueous and hexane extracts of the leaves showed very strong activities (MICof $39 \mu \mathrm{g} / \mathrm{mL}$ ). The antimicrobial activity for the samples is presented in Table III.

Total activity values (Table III) revealed that the aqueous extract of $M$. multifida was the most active against C. albicans (ATCC 18804) as its antifungal component can be diluted in $8666.7 \mathrm{~mL}$ of solvent 


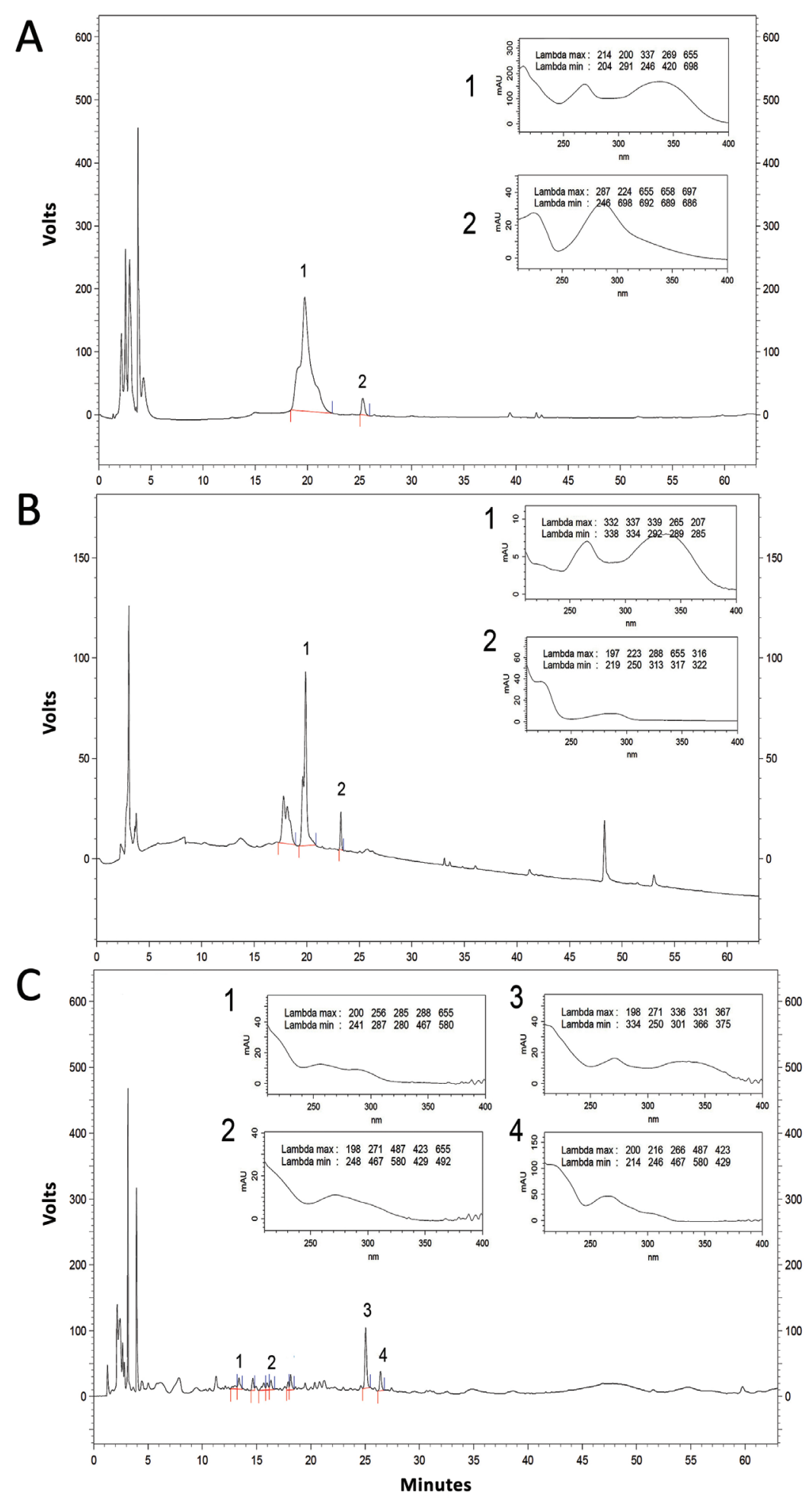

Figure 1 - The HPLC profiles of the extracts of M. multifida. (A) methanolic leaves extract; (B) aqueous leaves extract and (C) methanolic fruits extract. Column Zorbax SB-C18; linear gradient of a binary solvent system, A:B, which varied from 0 to $100 \%$ B was run at a flow rate of $1 \mathrm{ml} / \mathrm{min}$ over sixty minutes where A consists of acetonitrile: $\mathrm{H}_{2} \mathrm{O}, 5: 95$, with $0.05 \%$ TFA and $\mathrm{B}$ consists of acetonitrile: $\mathrm{H}_{2} \mathrm{O}, 65: 35$, with $0.05 \%$ TFA. The mobile phase was returned to its original composition over the course of 60 minutes. The sample volume was $20 \mu \mathrm{l}$ at a concentration of $1 \mathrm{mg} / \mathrm{ml}$ and the temperature was maintained at $25^{\circ} \mathrm{C}$ during the analysis. Detection was performed at $220 \mathrm{~nm}$. 
TABLE II

Antioxidant activity and cytotoxicity against Artemia salina of Manihot multifida extracts.

\begin{tabular}{lll}
\hline Samples & $\begin{array}{l}\text { DPPH assay } \\
\mathbf{I C}_{\mathbf{5 0}}(\boldsymbol{\mu g} / \mathbf{m L})^{\mathbf{a}}\end{array}$ & $\begin{array}{l}\text { Cytotoxicity } \\
\mathbf{L C}_{\mathbf{5 0}}(\boldsymbol{\mu g} / \mathbf{~ m L})^{\mathbf{a}}\end{array}$ \\
\hline $\begin{array}{lll}\text { Fruits } \\
\text { Methanolic extract }\end{array}$ & $135.1(100.8-181.1)$ & $34.1(18.0-64.5)$ \\
Hexane extract & $>250.0$ & $89.8(48.7-120.7)$ \\
Leaves & & \\
Aqueous extract & $130.8(99.2-172.4)$ & $>250.0$ \\
Methanolic extract & $46.9(38.3-57.3)$ & $15.6(9.0-23.5)$ \\
$\begin{array}{l}\text { Hexane extract } \\
\text { Rutin }^{\mathrm{b}}\end{array}$ & $59.2(49.2-71.3)$ & $>250.0$ \\
Tymol $^{\mathrm{b}}$ & $1.4(1.1-1.8)$ & \\
\hline
\end{tabular}

${ }^{a}$ The results in parentheses are the $95 \%$ confidence limits; ${ }^{b}$ Positive controls.

and still inhibit the growth of this yeast (total activity of $8666.7 \mathrm{~mL} / \mathrm{g}$ ). This is followed by the activity of hexane extract of leaves and methanolic extract of fruits against $C$. albicans (ATCC 18804) (total activity of 2512.8 and $1820.5 \mathrm{~mL} / \mathrm{g}$, respectively). Total activity of the other samples was below $500 \mathrm{~mL} / \mathrm{g}$.

MSI values (Table IV) were useful in evaluating the susceptibility of the different strains of microbes to the plant extracts investigated. C. albicans (ATCC 18804) and S. aureus (ATCC 6538) were the test organisms found to be the most susceptible to the samples investigated (MSI of 80 and 60, respectively). On the other hand, $S$. typhimurium (ATCC 13311) was resistant to all samples tested.

Among the samples evaluated, the methanolic and hexane extracts of fruits were the most efficient (50\% activity) against the different microorganisms used (Table V).

These results corroborated the popular use of M. multifida against skin infections caused by Candida sp. which might include sexually transmitted diseases, mainly in immunosuppressed patients with HIV infection, as they become more susceptible to opportunistic micro-organisms such as Candida sp. (Hamza et al. 2006).

Aiyelaagbe et al. $(2007,2008)$ also found antimicrobial activities of $M$. multifida (stem and
TABLE III

Minimum inhibitory concentration values of the samples (MIC values $\leq 2500 \mu \mathrm{g} / \mathrm{mL}$ ) and their total activity.

\begin{tabular}{|c|c|c|c|}
\hline Samples & Micro-organisms & $\begin{array}{l}\text { MIC }^{\mathrm{a}, \mathrm{b}} \\
(\mu \mathrm{g} / \mathrm{mL})\end{array}$ & $\begin{array}{l}\text { Total } \\
\text { activity }^{c} \\
(\mathrm{~mL} / \mathrm{g})\end{array}$ \\
\hline \multicolumn{4}{|c|}{ Fruits } \\
\hline \multirow[t]{2}{*}{$\begin{array}{l}\text { Methanolic } \\
\text { extract }\end{array}$} & $\begin{array}{l}\text { Staphylococcus aureus } \\
\text { (ATCC 6538) }\end{array}$ & 2500 & 28.4 \\
\hline & $\begin{array}{l}\text { Candida albicans } \\
\text { (ATCC 18804) }\end{array}$ & 39 & 1820.5 \\
\hline \multirow[t]{3}{*}{$\begin{array}{l}\text { Hexane } \\
\text { extract }\end{array}$} & $\begin{array}{l}\text { Bacillus cereus } \\
\text { (ATCC 11778) }\end{array}$ & 2500 & 52.0 \\
\hline & $\begin{array}{l}\text { Staphylococcus aureus } \\
\text { (ATCC 6538) }\end{array}$ & 2500 & 52.0 \\
\hline & $\begin{array}{l}\text { Escherichia coli } \\
\text { (ATCC 10536) }\end{array}$ & 2500 & 52.0 \\
\hline \multicolumn{4}{|c|}{ Leaves } \\
\hline $\begin{array}{l}\text { Aqueous } \\
\text { extract }\end{array}$ & $\begin{array}{l}\text { Candida albicans } \\
\text { (ATCC 18804) }\end{array}$ & 39 & 8666.7 \\
\hline \multirow[t]{3}{*}{$\begin{array}{l}\text { Methanolic } \\
\text { extract }\end{array}$} & $\begin{array}{l}\text { Staphylococcus aureus } \\
\text { (ATCC 6538) }\end{array}$ & 2500 & 93.6 \\
\hline & $\begin{array}{l}\text { Escherichia coli } \\
\text { (ATCC 10536) }\end{array}$ & 2500 & 93.6 \\
\hline & $\begin{array}{l}\text { Candida albicans } \\
\text { (ATCC 18804) }\end{array}$ & 625 & 374.4 \\
\hline \multirow[t]{3}{*}{$\begin{array}{l}\text { Hexane } \\
\text { extract }\end{array}$} & $\begin{array}{l}\text { Streptococcus pyogenes } \\
\text { (ATCC 10096) }\end{array}$ & 625 & 156.8 \\
\hline & $\begin{array}{l}\text { Bacillus cereus } \\
\text { (ATCC } 11778 \text { ) }\end{array}$ & 2500 & 39.2 \\
\hline & $\begin{array}{l}\text { Candida albicans } \\
\text { (ATCC 18804) }\end{array}$ & 39 & 2512.8 \\
\hline
\end{tabular}

${ }^{\mathrm{a}}=$ MIC: Minimum Inhibitory Concentration; ${ }^{\mathrm{b}}=$ MIC of standards: Chloramphenicol (Staphylococcus aureus (ATCC 6538)- 62.5 $\mu \mathrm{g} / \mathrm{mL}$; Bacillus cereus (ATCC 11778) - 3.91 $\mu \mathrm{g} / \mathrm{mL}$; Escherichia coli (ATCC 10536) - $15.6 \mu \mathrm{g} / \mathrm{mL}$; Streptococcus pyogenes (ATCC 10096) - $31.3 \mu \mathrm{g} / \mathrm{mL}$ ) and Amphotericin B (Candida albicans (ATCC 18804) - 0.39 $\mu \mathrm{g} / \mathrm{mL}) .^{\mathrm{c}}=$ Total activity: indicates the degree to which biologically active compounds in $1 \mathrm{~g}$ of plant material can be diluted and still inhibit the growth of micro-organisms.

roots) and $M$. podagarica (roots) and reported diterpenoids with antibacterial activity against some gram-positive bacteria.

Buch et al. (2008) showed the wound healing action of the latex of $M$. multifida leaves. It is well established that latex is rich in terpenoids that have antimicrobial actions (Samlipto et al. 1989).

Based on the chemical classes detected in chromatographic analyzes, the possible antimicrobial 
TABLE IV

Microbial susceptibility index, MSI, calculated for the different strains of microorganisms used for screening of Manihot multifida extracts (MIC values $\leq 2500 \mu \mathrm{g} / \mathrm{mL}$ ).

\begin{tabular}{ccc}
\hline Test organisms & $\begin{array}{c}\text { Number of } \\
\text { active extracts }\end{array}$ & $\begin{array}{c}\text { MSI } \\
\text { values }^{\mathbf{a}}\end{array}$ \\
\hline $\begin{array}{c}\text { Staphylococcus aureus } \\
\text { (ATCC 6538) }\end{array}$ & 3 & 60 \\
$\begin{array}{c}\text { Escherichia coli } \\
\text { (ATCC 10536) }\end{array}$ & 2 & 40 \\
$\begin{array}{c}\text { Salmonella typhimurium } \\
\text { (ATCC 13311) }\end{array}$ & 0 & 0 \\
$\begin{array}{c}\text { Bacillus cereus } \\
\text { (ATCC 11778) }\end{array}$ & 2 & 40 \\
$\begin{array}{c}\text { Streptococcus pyogenes } \\
\text { (ATCC 10096) } \\
\text { Candida albicans } \\
\text { (ATCC 18804) }\end{array}$ & 1 & 20 \\
\hline
\end{tabular}

${ }^{a}$ MSI: Microbial Susceptible Index

TABLE V

Percent activity values of Manihot multifida extracts

(MIC values $\leq 2500 \mu \mathrm{g} / \mathrm{mL}$ ), demonstrating the total anti-microbial potency of the extracts.

\begin{tabular}{ccc}
\hline Samples & $\begin{array}{c}\text { Number of } \\
\text { susceptible } \\
\text { microbial } \\
\text { strains }\end{array}$ & $\begin{array}{c}\text { Percent activity } \\
\text { values (\%) }\end{array}$ \\
\hline Fruits \\
\hline Methanolic extract & 2 & 33 \\
Hexane extract & 3 & 50 \\
\hline & Leaves & \\
\hline Aqueous extract & 1 & 50 \\
Methanolic extract & 3 & 50 \\
Hexane extract & 3 &
\end{tabular}

mechanisms of action thought to be responsible for some phenylpropanoids (phenolics) toxicity to micro-organisms includes enzyme inhibition by the oxidized compounds, possibly thought reaction with sulfhydryl groups or thought more nonspecific interactions with the proteins (Mason and Wasserman 1987). Flavones activities are probably due to their ability to complex with extracellular and soluble proteins and to complex with extracellular cell walls (Dixon et al. 1983).

\section{CONCLUSIONS}

In conclusion, these results corroborate the popular use of this specie in treating fungal infections as it demonstrated significant activity against C. albicans (ATCC 18804). M. multifida could be of use a source of natural antioxidant and microbial components for the food supplement or pharmaceutical industry. Active compounds are being isolated for chemical characterization.

\section{ACKNOWLEDGMENTS}

The authors are grateful to Plataforma Analítica - Farmanguinhos/FIOCRUZ and Dr. Marcus Alberto Nadruz Coelho - JBRJ for the botanical identification of the species.

\section{RESUMO}

Manihot multifida (L.) Crantz (Euphorbiaceae) é amplamente utilizada na medicina popular no tratamento de feridas infectadas. Esse estudo avaliou o potencial antioxidante e antimicrobiano in vitro de extratos dessa espécie frente às cepas bacterianas Gram-positiva e Gramnegativa e fungo que causam infecções em humanos. Os extratos mostraram concentração inibitória mínima (CIM) variando de 39 a $2500 \mu \mathrm{g} / \mathrm{mL}$ para a atividade antimicrobiana. $\mathrm{O}$ extrato metanólico de frutos, hexânico e aquoso de folhas mostraram atividade muito forte para Candida albicans (ATCC 18804), com CIM de $39 \mu \mathrm{g} / \mathrm{mL}$. Além disso, o extrato metanólico de folhas de M. multifida mostrou potencial antioxidante contra o radical DPPH com valor de concentração inibitória $\left(\mathrm{Cl}_{50}\right)$ de $46,9 \mu \mathrm{g} / \mathrm{mL}$, seguido pelo extrato hexânico de folhas, com valor de $\mathrm{CI}_{50}$ de $59,2 \mu \mathrm{g} / \mathrm{mL}$. A atividade citotóxica foi maior no extrato

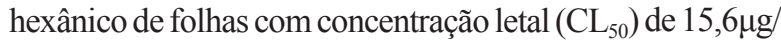
$\mathrm{mL}$. Esses resultados sugerem que M. multifida possui atividades antimicrobiana e antioxidante interessantes. Sendo assim, corroboram o uso popular dessa espécie no tratamento de infecções fúngicas, uma vez que demonstrou uma atividade significativa frente à $C$. albicans.

Palavras-chave: antimicrobiano, antioxidante, Candida albicans, citotoxicidade, Manihot multifida. 


\section{REFERENCES}

AiyelaAgBe OO, Adesogan K, EkUndayo O AND GloeR JB. 2007. Antibacterial diterpenoids from Jatropha podagarica Hook. Phytochemistry 68: 2420-2425.

AiYelaAgBe OO, OGUnTUASE BJ, ARIMAH BD AND AdENIYI BA. 2008. The antimicrobial activity of Jatropha multifida extracts and chromatographic fractions against sexually transmitted infections. J Med Sci 8: 143-147.

Aligiannis N, Kalpotzakis E, Mitaku S AND Chinou IB. 2001. Composition and antimicrobial activity of the essential oils of two Origanum species. J Agr Food Chem 40: 4168-4170.

BROADHURST CL, POLANSKY MM AND ANDERSON RA. 2000. Insulin-like activity of culinary and medicinal plant aqueous extracts in vitro. J Agr Food Chem 48: 849-852.

BUCH DR, ARANTES AB AND CAMPELO PMS. 2008. Verificação da atividade cicatrizante do exudato de folhas de Jatropha multifida L. Rev Bras Farm 89: 142-145.

DAS B, RaVikanth B, LAXMinarayana K, Ramarao B AND RAJU TV. 2009. New macrocyclic diterpenoids from Jatropha multifida. Chem Pharm Bull 57: 318-320.

DAs B, RAVIKANTH B, REDDY KR, ThIRUPATHI P, RAJU TV AND SRIDHAR B. 2008. Diterpenoids from Jatropha multifida. Phytochemistry 69: 2639-2641.

DiXON RA, DEY PM AND LAMB CJ. 1983. Phytoalexins: enzymology and molecular biology. Adv Enzymol RAMB 55: $1-136$.

ELLOF JN. 2004. Quantifying the bioactivity of plant extracts during screening and bioassay-guided fractionation. Phytomedicine 11: 370-371.

GOVIDARAJAN R, RASTOGI S, VIJAYAKUMAR M, SHIRWAIKAR A, RaWAT AKS AND Mehrotra S. 2003. Studies on the antioxidant activities of Desmodium gangeticum. Biol Pharm Bull 26: 1424-1427.

Hamza OJM, VAN Den Bout-VAN DEN Beukel CJP, Matte MIN, Moshi MJ, Mikx FHM and SElemani HO. 2006. Antifungal activity of some Tanzanian plants used traditionally for the treatment of fungal infections. J Ethnopharmacol 108: 124-132.

Kosasi S, VAN Der Sluis WG, Boelens R, 'T Hart LA AND LABADIE RP. 1989. Labaditin: a novel cyclic decapeptide from the latex of Jatropha multifida L. (Euphorbiaceae): Isolation and sequence determination by means of twodimensional NMR. FEBS Lett 256: 91-96.
Martins LGS, Senna-Valle L and Pereira NA. 2005. Princípios ativos e atividades farmacológicas de oito plantas popularmente conhecidas por nome de medicamentos comerciais. Rev Bras Plantas Med 7: 73-76.

MASON TL AND WASSERMAN BP. 1987. Inactivation of red beet betaglucan synthase by native and oxidized phenolic compounds. Phytochemistry 26: 2197-2202.

Mclaughlin JL, Rogers LL And ANDERSON JE. 1998. The use of biological assays to evaluate botanicals. Drug Inf J 32: 513-524.

MClauglin JL, Chang CJ AND SMITH DL. 1991. Bench-top bioassays for the discovery of bioactive natural products: an update. In: RAHMAN A (Ed), Studies in natural products chemistry, London: Pergamon Press, London, p. 383-389.

MEyer BN, Ferrigni NR, Putnam JE, JACOBSEN LB, Nichols DE AND MaClaughlin JL. 1982. Brine shrimp: A convenient general bioassay for active plant constituents. Planta Med 45: 31-34.

MidDleton E AND Kandaswami C. 1992. Effects of flavonoids on immune and inflammatory cell function. Biochem Pharmacol 43: 1167-1179.

Moharram FA, Marzouk MS, HagGaG EG, Ei-Batran S AND IBRAHIM RR. 2007. Biological examination and novel biflavone di-C-glycosides from Jatropha multifida L. leaves. Planta Med 7: 839-848.

NCCLS - NATIONAL COMMITTEE FOR CLINICAL LABORATORY STANDARDS. Reference method for broth dilution antifungal susceptibility testing of yeasts. 2002. Approved standard M27-A2 - P. National Committee for Clinical Laboratory Standards. Wayne PA, 2002, 31 p.

OSAWA T. 1994. Novel natural antioxidants for utilization in food and biological systems. In: Uritany I, GARCIA VV and Mendoza EM (Eds), Postharvest biochemistry of plant food - Materials in tropics, Tokyo: Scientific Society Press, Tokyo, p. 241-251.

RIESER MJ, GU ZM, FrANG I, WoOd KV AND MCLAUGHLIN JL. 1996. Five novel mono-tetrahydrofuran ring acetogenins from seeds of Annona muricata. J Nat Prod 59: 100-108.

SAMLiPto K, Willem G AND Rudi PL. 1989. Multifidol and multifidol glucoside from the latex of Jatropha multifida. Phytochemistry 28: 2439-2441. 
